\title{
TINJAUAN YURIDISPENIPUAN PENJUALAN BATIK TULIS MELALUI TRANSAKSI DI INTERNET
}

\author{
Oleh: \\ Maurice Rogers ${ }^{1)}$ \\ Edison Sianturi ${ }^{2)}$ \\ Universitas Darma Agung, Medan 1,2) \\ E-mail: \\ $\frac{\text { maurice_rogers09@yahoo.com }}{\text { edisonsianturi9034@gmail.com }}{ }^{2)}$
}

\begin{abstract}
In previous time, Batik was used based on the objectives that surrounded it. Many people are deceived by the high prices offered by buyers assessing written and original Batik, valued at millions of rupiah. In this research, a normative study is used, through the approach of IT laws and regulations with written Batik. If you observe a fake batik or not original Batik it is processed by integrating screen printing. Batik motifs are closed using the night with a printing tool for screen printing after the color dyeing process such as the batik process. Ignorance and misperception of consumers who think that batik printing batik products are the same as batik product; in fact give disadvantages to batik producers and consumers themselves. The sales turnover of batik producers goes down, because consumers tend to buy batik printing textile products that have a much cheaper price than batik products and consumers become vulnerable to fraud efforts from dishonest batik producers, who say that the products they sell are batik products but actually is a textile product printing batik motifs.
\end{abstract}

Keyword: Deception, Batik Writing

\begin{abstract}
ABSTRAK
Zaman dulu batik dipakai berdasarkan tujuan yang melingkupinya. Banyak orang tertipu dengan harga mahal yang ditawari pembeli menilai batik tulis maupun batik cap yang asli, dihargai jutaan rupiah. Adapun metode penulisan dalam penelitian skripsi ini memakai studi normatif, melalui pendekatan peraturan perundang-undangan ITE dengan batik tulis. Jika diamati tiruan batik alias bukan batik asli karena diproses dengan cara memadukan sablon. Motif batik ditutup menggunakan malam dengan alat printing untuk sablon setelah proses pencelupan warna seperti proses pembatikan. Ketidaktahuan serta kesalahan persepsi konsumen yang menganggap produk tekstil printing motif batik adalah sama dengan produk batik, ternyata memberikan kerugian untuk produsen batik dan konsumen itu sendiri. Omset penjualan produsen batik menjadi turun, karena konsumen cenderung membeli produk tekstil printing motif batik yang memiliki harga jauh lebih murah dibanding produk batik dan konsumen menjadi rentan dengan upaya penipuan dari produsen batik yang tidak jujur, yang menyebutkan bahwa produk yang dijualnya tersebut adalah produk batik namun sebenarnya adalah produk tekstil printing motif batik.
\end{abstract}

Keyword: Penipuan, Batik Tulis

\section{PENDAHULUAN}

Banyak di antara aparat penegak hukum yang tidak mengetahui bahwa tindakan peniruan atau penjiplakan motif seni batik di kalangan pengusaha batik juga merupakan suatu tindak pidana di bidang hak cipta. Dapat dikatakan bahwa wawasan dan 
pengetahuan para penegak hukum di bidang hak cipta seni batik masih rendah sehingga mereka mengesampingkan kasus-kasus pelanggaran yang terjadi.

Kain yang ini lebih halus penipuannya karena menggunakan teknik melekatkan bahan kimia cabut warna untuk membentuk motif. Mempercepat waktu produksi dan menghemat bahan adalah bentuk kecurangan yang dilakukan si empunya usaha. Sampai tahap itu biasanya akan dikombinasikan dengan menggoreskan canting tulis dan atau canting cap untuk menaruh kesan kepada pembeli bahwa yang mereka hasilkan adalah batik tulis.

Pelanggaran terhadap hak cipta batik tradisional juga dapat dilakukan penuntutan ke Pengadilan Negeri oleh pihak Kejaksaan apabila ketentuan Pasal 72 dan 73 Undang-Undang Hak Cipta Dilanggar.

Pada Undang-Undang Republik Indonesia No. 19 Tahun 2002 Tentang Hak Cipta yang lama, suatu pelanggaran hak cipta dikategorikan sebagai delik biasa yang berarti bahwa penanganan terhadap npelanggaran hak cipta dapat dilakukan oleh penyidik atau aparat penegak hukum tanpa harus menunggu adanya pengaduan dari masyarakat atau pencipta /pemegang hak cipta.

Berdasarkan sistem delik biasa, satu kasus pelanggaran hak cipta daat segera ditangani oleh penyidik /aparat penegak hukum sehingga kerugian yang imbul dapat dicegah seminimal mungkin. Namun demikian dalam perkembangan selanjutnya kategori delik pada Undang-Undang Republik Indonesia No. 19 Tahun 2002 Tentang Hak Cipta yang baru mengalami perubahan sehingga berdasarkan ketentuan Undang-Undang Republik Indonesia No. 19 Tahun 2002 Tentang Hak Cipta, pelanggarab suatu hak cipta dikategorikan sebagai delik aduan.
Dalam Pasal 12 dinyatakan Pelaku usaha dilarang menawarkan, mempromosikan atau mengiklankan suatu barang dan/atau jasa dengan harga atau tarif khusus dalam waktu dan jumlah tertentu, jika pelaku usaha tersebut tidak bermaksud untuk melaksanakannya sesuai dengan waktu dan jumlah yang ditawarkan, dipromosikan, atau diiklankan.

Dalam Pasal 13 dinyatakan Pelaku usaha dilarang menawarkan, mempromosikan, atau mengiklankan suatu barang dan/atau jasa dengan cara menjanjikan pemberian hadiah berupa barang dan/atau jasa lain secara cumacuma dengan maksud tidak memberikannya atau memberikan tidak sebagaimana yang dijanjikannya.

Setiap pelaku usaha yang melanggar hak-hak konsumen dikenakan sanksi. Pada dasarnya, hubungan antara konsumen dan pelaku usaha adalah hubungan hukum keperdataan, tapi Undang-undang Perlindungan Konsumen.

Pelaku usaha yang melanggar hak-hak konsumen dikenakan sanksi. Pada dasarnya, hubungan antara konsumen dan pelaku usaha adalah hubungan hukum keperdataan, tapi Undang-undang Perlindungan Konsumen juga mengenakan sanksi pidana bagi pelanggar hak-hak konsumen. Sebagaimana disebutkan dalam Undang-undang Perlindungan Konsumen Pasal 45 ayat 3, "Penyelesaian sengketa diluar pengadilan sebagaimana dimaksud pada ayat 2 tidak menghilangkan tanggung jawab pidana

\section{TINJAUAN PUSTAKA}

Batik ( atau kata Batik ) berasal dari bahasan Jawa " Amba " yang berarti menulis dan " titik". Kata batik merujuk pada kain dengan corak yang dihasilkan oleh bahan " malam " ( wax ) 
yang diaplikasikan ke atas kain, sehingga menahan masuknya bahan pewarna (dye), atau dalam Bahasa Inggrisnya “ Wax-Resist dyeing”. Batik adalah kerajinan yang memiliki nilai seni tinggi dan telah menjadi bagian dari budaya Indonesia ( khususnya Jawa) sejak lama.

Produk yang diproduksi oleh rumah produksi batik, dapat dibedakan menjadi 4 macam yakni:

1. Batik tulis;

2. Batik cap

3. Tekstil printing bermotif batik

4. Kombinasi

Batik local memiliki keunggulan dibandingkan batik impor dan bahwa produk batik tulis atau batik cap memiliki pasarnya sendiri karena kemampuan pilihan konsumen membeli dan menggunakan batik local.

Batik merupakan teknik menghias kain atau tekstil dengan menggunakan lilin dalam proses pencelupan warna, dimana semua proses tersebut menggunakan tangan. Pengertian lain dari batik adalah seni tentang warna yang meliputi proses pemalaman (pemawarnaan) dan pelorotan (pemanasan), hingga menghasilkan motif yang halus yang semuanya ini memerlukan ketelitian yang tinggi.

Batik adalah sehelai wastra yakni sehelai kain yang dibuat secara tradisional dan terutama juga digunakan dalam matra tradisional beragam hias pola tertentu yang pembuatannya menggunakan teknik celup rintang dengan malam ( lilin batik ) sebagai bahan perintang warna. Oleh karena itu suatu wastra dapat disebut batik apabila mengandung dua unsur pokok, yaitu teknik celup rintang, yang menggunakan lilin sebagai perintang warna dan pola yang beragam hias khas batik.
Batik juga diperingati setiap tanggal 02 Oktober, sebagai Hari Batik Nasional. Ada beberapa jenis batik dengan harga termahal di Indonesia, yaitu:

\section{Batik Tiga Negeri}

Batik Tiga Negeri adalah jenis batik Indonesia yang terdiri dari tiga warna berbeda. Corak, motif dan kombinasi warna yang satu ini menunjukkan bahwa proses pembuatan menjadi poin penting. Tidah heran kalau harga per meter kain Batik Tiga Negeri ini dibanderol dengan harga cukup mencengangkan, yakni di atas Rp100 juta.Batik Tiga Negeri di Jawa Tengah memiliki aneka ragam versi cerita. Mulai dari batik yang mengalami proses pewarnaan di tiga tempat yaitu Lasem, Pekalongan, Solo sampai ke batik tiga warna yang sejatinya terdiri dari warna merah, biru, kuning, soga. Motifnya diamini sebagai motif akulturasi Jawa, Arab, Eropa, Cina.

2. Batik Indonesia Corak belanda

Batik Indonesia Corak Belanda ini berawa; dari warga keturunan Belanda yang tertarik dengan corak dan motif batik Indonesia.Akhirnya, mereka membuat batik dengan motif sendiri yang lebih disukai bangsa Eropa. Motif berupa bunga-bunga Eropa seperti tulip dan motif tokoh-tokoh cerita dongeng terkenal di sana.

Corak dan batik jenis ini juga dikenal dengan Batik Belanda karena dikembangkan oleh wanita Indo-Eropa antara 1840 dan 1940. Ada banyak jenis motif batik yang dikembangkan saat itu dan kemudian dikenal dengan nama batik pembuatnya. Selembar kain Batik Corak Belanda mencapai Rp100 juta dan harga ini bisa melambung lagi jika sudah masuk di balai lelang.

3. Batik halus Cirebon

Kain Batik Halus Cirebon bisa mencapai $\mathrm{Rp} 30$ juta. Nilai tersebut bukan hanya dilihat dari sulitnya proses 
pembuatannya tetapi makna dari corak dan moti dalam kain Batik Halus Cirebon ini. Jangan samakan Batik Halus Cirebon ini dengan batik yang ada saat ini. Batik jenis ini bukanlah batik cap atau printing. Batik Halus Cirebon dibuat dengan cara ditulis atau dikenal dengan batik tulis. Untuk bisa menyelesaikan pembuatan selembar kain batik membutuhkan waktu sekitar satu tahun lamanya. Jadi pantas saja kalau harganya hingga puluhan juta rupiah.

4. Kain Batik Kerajaan

Batik Kerajaan adalah batik karya asli seorang raja pada zaman dahulu. Sang raja ini biasanya terinspirasi dari sebuah keris atau Parang Barong yang melambangkan kekuasaan dan kebijaksanaan tertinggi. Tentu harga batik ini juga mahal, bisa mencapai Rp100 juta

\section{Batik Hokokai}

Hokokai mempunyai desain dan corak berbentuk bunga sakura, desainnya sangat kecil tetapi tetap detail dan rapi.Namanya memang ada unsur kejepang-jepangan, karena sejarahnya pembuatan batik ini memang diperuntukkan kepada Kaisar Jepang. Di Indonesia, batik ini dimiliki oleh Tumbu Ramelan, dan untuk harganya diperkirakan di atas Rp100 juta.

Banyaknya permintaan batik di pasar domestic membuat sector batik tulis menjanjinkan termasuk untuk Pasar batik printing atau tekstil bermotif batik.Pertama, warna batik. Batik tulis asli memiliki warna natural, solid, dan kuat. Selain itu motif batik tulis terlihat kurang rapih, karena disebabkan pengerjaan yang dilakukan dengan tangan.

Penipuan yang dilakukan oleh penjual dalam jual beli online, seperti menggunakan identitas palsu, maka penjual tersebut dapat dipidana berdasarkan Pasal 378 Kitab Undang-
Undang Hukum Pidana (KUHP) tentang penipuan dan Pasal 28 ayat (1) UndangUndang Nomor 11 Tahun 2008 tentang Informasi dan Transaksi Elektronik (UU ITE) tentang menyebarkan berita bohong dan menyesatkan yang mengakibatkan kerugian konsumen dalam Transaksi Elektronik.

Unsur-unsur penipuan melalui IT dalam Pasal 28 ayat (1) antara lain:

1. Setiap orang dengan sengaja;

2. Tanpa hak menyebarkan berita bohong dan menyesatkan

3. Yang menyesatkan yang mengakibatkan kerugian konsumen dalam transaksi elektronik

4. Diancam karena penipuan dengan pidana penjara lama 6 tahun dan denda paling banyak Rp 1 Milyar (Pasal 45 ayat (2) Undang-undang ITE ).

\section{METODE PELAKSANAAN}

Jenis penelitian yang digunakan dalah penelitian yuridis normatif.Penelitian hukum normatif yang menitikberatkan pada penelitian kepustakaan dan berdasarkan pada bahan hukum sekunder. Bahan hukum primer adalah UU Nomor 19 Tahun 2016 tentang Informasi dan Transaksi Elektronik, Undang-undang Nomor 8 Tahun 1999 Tentang Perlindungan Konsumen

\section{HASIL DAN PEMBAHASAN}

Pertanggungjawaban Pidana

Pengelola Situs Belanja Batik Tulis Terhadap Kerugian Yang Dialami Konsumen Pada Saat Bertransaksi Jual Beli Batik Tulis Melalui Situs Belanja Online.

Apabila pelaku usaha melanggar larangan memperdagangkan barang/jasa yang tidak sesuai dengan janji yang dinyatakan dalam label, etiket, keterangan, iklan atau promosi penjualan barang dan/atau jasa tersebut, 
maka pelaku usaha dapat dipidana berdasarkan Pasal 62 ayat (1) UU Perlindungan Konsumen yang berbunyi:

Pelaku usaha yang melanggar ketentuan sebagaimana dimaksud dalam Pasal 8, Pasal 9, Pasal 10, Pasal 13 ayat (2), Pasal 15, Pasal 17 ayat (1) huruf $a$, huruf $b$, huruf $c$, huruf e, ayat (2) dan Pasal 18 dipidana dengan pidana penjara paling lama 5 (lima) tahun atau pidana denda paling banyak Rp 2 miliar.

Kontrak Elektronik dan Perlindungan Konsumen Menurut UU ITE dan PP PSTETransaksi jual beli Anda, meskipun dilakukan secara online, berdasarkan UU ITE dan PP PSTE tetap diakui sebagai transaksi elektronik yang dapat dipertanggungjawabkan. Persetujuan Anda untuk membeli barang secara online dengan cara melakukan klik persetujuan atas transaksi merupakan bentuk tindakan penerimaan yang menyatakan persetujuan dalam kesepakatan pada transaksi elektronik. Tindakan penerimaan tersebut biasanya didahului pernyataan persetujuan atas syarat dan ketentuan jual beli secara online yang dapat kami katakan juga sebagai salah satu bentuk Kontrak Elektronik.

a. terdapat kesepakatan para pihak;

b. dilakukan oleh subjek hukum yang cakap atau yang berwenang mewakili sesuai dengan ketentuan peraturan perundang-undangan;

c. terdapat hal tertentu; dan

d. objek transaksi tidak boleh bertentangan dengan peraturan perundang-undangan,

kesusilaan, dan ketertiban umum.
Kontrak Elektronik itu sendiri setidaknya harus memuat hal-hal sebagai berikut:

a. data identitas para pihak;

b. objek dan spesifikasi;

c. persyaratan Transaksi Elektronik;

d. harga dan biaya;

e. prosedur dalam hal terdapat pembatalan oleh para pihak;

f. ketentuan yang memberikan hak kepada pihak yang dirugikan untuk dapat mengembalikan barang dan/atau meminta penggantian produk jika terdapat cacat tersembunyi; dan

g. pilihan hukum penyelesaian Transaksi Elektronik.

jual beli secara online pada prinsipnya adalah sama dengan jual beli secara faktual pada umumnya. Hukum perlindungan konsumen terkait transaksi jual beli online pun sebagaimana kami jelaskan sebelumnya tidak berbeda dengan hukum yang berlaku dalam transaksi jual beli secara nyata. Pembedanya hanya pada penggunaan sarana internet atau sarana telekomunikasi lainnya. Akibatnya adalah dalam transaksi jual beli secara online sulit dilakukan eksekusi ataupun tindakan nyata apabila terjadi sengketa maupun tindak pidana penipuan. Sifat siber dalam transaksi secara elektronis memungkinkan setiap orang baik penjual maupun pembeli menyamarkan atau memalsukan identitas dalam setiap transaksi maupun perjanjian jual beli.

Dalam hal pelaku usaha atau penjual ternyata menggunakan identitas palsu atau melakukan tipu muslihat dalam jual beli online tersebut, maka pelaku usaha dapat juga dipidana berdasarkan Pasal 378 Kitab Undang-Undang Hukum Pidana(KUHP) tentang penipuan dan Pasal 28 ayat (1) UU ITE tentang menyebarkan berita 
bohong dan menyesatkan yang mengakibatkan kerugian konsumen dalam Transaksi Elektronik.Pasal 378 KUHP adalah sebagai berikut:

Barangsiapa dengan maksud untuk menguntungkan diri sendiri atau orang lain secara melawan hukum, dengan memakai nama palsu atau martabat palsu, dengan tipu muslihat, ataupun rangkaian kebohongan, menggerakkan orang lain untuk menyerahkan barang sesuatu kepadanya, atau supaya memberi hutang maupun menghapuskan piutang, diancam karena penipuan dengan pidana penjara paling lama empat tahun.

Pasal 28 ayat (1) UU ITE adalah sebagai berikut:

Setiap Orang dengan sengaja, dan tanpa hak menyebarkan berita bohong dan menyesatkan yang mengakibatkan kerugian konsumen dalam Transaksi Elektronik.

Terhadap pelanggaran Pasal 28 ayat (1) UU ITE ini diancam pidana sebagaimana diatur dalam Pasal 45A ayat (1) UU 19/2016, yakni:

Setiap Orang yang dengan sengaja dan tanpa hak menyebarkan berita bohong dan menyesatkan yang mengakibatkan kerugian konsumen dalam Transaksi Elektronik sebagaimana dimaksud dalam Pasal 28 ayat (1) dipidana dengan pidana penjara paling lama 6 (enam) tahun dan/atau denda paling banyak Rp1.000.000.000,00 (satu miliar rupiah).

Pertanggungjawaban Pidana Pengelola Situs Belanja Batik Tulis Terhadap Kerugian Yang Dialami
Konsumen Pada Saat Bertransaksi Jual Beli Batik Tulis Melalui Situs Belanja Online. Apabila pelaku usaha melanggar larangan memperdagangkan barang/jasa yang tidak sesuai dengan janji yang dinyatakan dalam label, etiket, keterangan, iklan atau promosi penjualan barang dan/atau jasa tersebut, maka pelaku usaha dapat dipidana berdasarkan Pasal 62 ayat (1) UU Perlindungan Konsumen

\section{SIMPULAN}

1. Seharusnya pengaturan tentang penjualan online perlu diatur lebih khsus lagi sehingga dalam pemasangan produk-produk dan jasa. Pelaku usaha batik tulis agar lebih memperhatikan perlindungan hukum bagi motif batik tulisnya dengan begitu pelaku usaha agar lebih menyadari pentingnya perlindungan hukum terhadap motif batik tulis ciptaanya. Bagi penjual online yang berusaha menjual batik tulis palsu, pelakunya dapat dihukum seberat-beratnya karena dianggap telah mencemarkan merek batik tulis Danar Hadi yang telah lama dipercayai masyarakat.

\section{DAFTAR}

PUSTAKA

\section{A. Buku-buku}

Arief,Barda Nawawi, 2003, Kapita Selekta Hukum Pidana, Bandung: Citra Aditya Bakti.

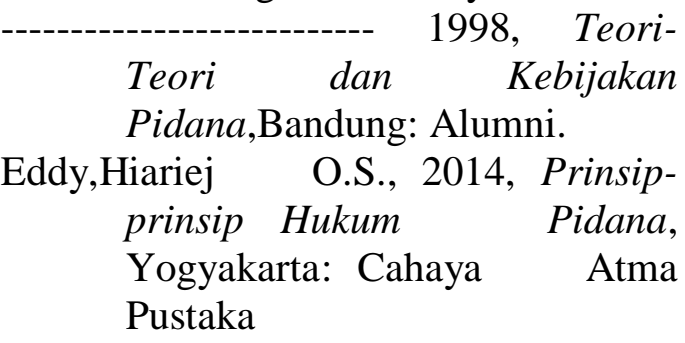

Hanafi, 1997, Strict Liability dan Vicarious Liability, dalam "Hukum Pidana", Yogyakarta: Lembaga Penelitian, Universitas Islam Indonesia 
Ibrahim, Johnny, 2007, Teori dan Metodologi Penelitian Hukum Normatif, Malang: Bayumedia Publishing.

Kristian, 2015, "Hukum Pidana Korporasi”, Bandung: Nuansa Aulia

Mahrus Ali, 2013, Asas-asas Hukum Pidana Korporasi, Rajawali Pers, Jakarta

Moeljatno, 2008, Azas-azas Hukum Pidana,Rineka Cipta, Jakarta.

Maramis,Frans, 2012, Hukum Pidana Umum dan Tertulis di Indonesia, Jakarta : Rajawali Pers

Pramono, Nindyo, 2006, "Bunga Rampai Hukum Bisnis Aktual”, Bandung: PT.Citra Aditya Bhakti

Priyatno, Dwidja, 2004, "Kebijakan Legislasi Tentang Sistem Pertanggungjawaban Pidana Korporasi Di Indonesia”, Bandung, CV Utomo.
2010

Pertanggungjawaban Pidana Korporasi, Jakarta:Kencana Prenadamedia Group.

Remi,Sjahdeini Sutan, 2006, "Pertanggungjawaban Pidana Korporasi", Jakarta: Grafiti Pers

Sjawie, Hasbullah F, 2013, Direksi Perseroan Terbatas serta Pertanggungjawaban Pidana Korporasi, Bandung: PT Citra Aditya Bakti.

\section{B. Peraturan Perundang-undangan}

Undang-undang Nomor19 Tahun 2002 tentang Hak Cipta

Undang-undang Nomor 19

Tahun 2016 tentang Informasi dan Transaksi ELektronik. 